〈書 評〉

\author{
厳 善平著 \\ 『中国の人口移動と民工 \\ 一マクロ・ミクロ・データに基づく計量分析』
}

$\langle 2005$ 年 11 月 1 日発行・勁草書房〉

\section{山口 三十四}

中国の労働力移動は 1990 年以降に非常に大きくな り, 2002 年には出稼ざに出た農村労衝力は, すでに 23. 2\%を占めるまでになっている. 本書はこの大きく なった労衝力移動をマクロ・ミクロ両データにより, 計 量的な要因分析を行ったものである。 そして，本書の 目次は次の様になっている.

序 章 問題意識, 課題と構成

第I 部 理論, 方法抢よび先行研究

第 1 章 労働移動研究の理論と方法一農村都市間 の労働移動を中心に

第 II 部 労働移動のマクロ・アプローチ

第 2 章 人口移動の実態と特徵一人ロセンサスの 集計資料の検討を中心に

第 3 章 省間人口移動とその決定要因一集計デー タによるマクロ分析

第 4 章 地域間人口移動の選択性一年齢, 学歴と 移動率の関係を中心に

第而部 労働移動のミクロ・アプローチ

第 5 章 農家の所得, 就業と貨金の決定要因 一農家調査の個票データによる分析

第 6 章 農村地域間の労㗢移動とその決定要因 一村レベルの個票データによる分析

第 7 章 出稼ぎ労働者の移動, 就業と生活 一上海市 1995 年流動人口調查の個票デー タをもとに

第 8 章 出稼ぎ学働市場の階層構造一上海市 1995 年流動人口調査の個票データを中心に

終 章 結論と展望

内容をごく簡潔に要約すると, 第 1 章は理論的説明 である、第 2 章は全国人口調査の集計資料を用い，年 間移動率が 90 年代を通し, 加速度的に上昇し, かつ移 動の広域化が進み、流出人口都市部のシェアーが拡 大し，広東省，上海市，北京市等への集中となってい
ると述べている。第 3 章注省間人口移動を分析し，広 域的な人口移動が急増し, 流入率には 1 人当たり総生 産，非国有部門従業者比率が正の関係を持つ点等，ま た 90 年代後半には, 非農業就業增加率が重要な影響に なった点，そしてトダローモデルを援用し，移動率が 所得水準, 就業機会の地域間格差, 距離, 情報伝達等 に依存すること等を示している，第 4 章法，中国も口 ジャース (Rogers) 等の人ロスケジュールの一定の法 則に従っている（後労働力成分がないものの）ことを 示している. 第 5 章は 7 県の県レベル個票データを用 い，年間就業日数，就業形態，非農業就業の賃金水準 が，男女性差，年齢，教育等とが統計的に有意性を示 す計量的分析を行っている. 第 6 章は 1995 年の工業を 中心とした経済発展がかなり進んだ村レベルの個票 データを用い，非農業就業者比率が急上昇したが地域 間格差が大きいこと, 東部を中心に郷外からの移入者 (特に季節的出稼ざ労働者)が激増したこと等を示して いる. 第 7 章と第 8 章は上海市の 1995 年の流動人口調 査の個票データを用いた分析で, 戸籍制度の規制緩和 により, 流動人口の激増があり, 出稼ぎ者は教育の高 い，非農業を前職に持った，結婚した青壮年の男性が 多いことを示している．しかし，大多数は地元住民の 敬遠する仕事と棲み分けがあること等を示し，第 8 章 はそれらを賃金関数の計測を通し，証明している．終 章は結論と展望である。

以上のように, 中国の労働力移動に関する膨大な データを整理し，多くの手段を用い，非常に多方面，か つ精力的な研究となっている．以下のような改良が必 要だが, 素晴らしい研究にいつもながら大きな敬意を 表したい. しかし, 論争的書評の性格上, あえて厳し い批判ないしはコメントを行うことにする。まず，第 1 に, 新古典派理論をルイスのみで代替し、ルイス批 判を繰り返している。，そして，ルイス理論に代わるも のとして、スジャースタッド（Sjaastad）の人的資本理 論, トダロー (Todaro) の確率雇用モデル, スターク (Stark) を中心とした新しい労働移動の経済学, カイン (Cain) 等の労働市場の階層化理論等を説明し、ルイス の批判をなしている。しかし, 新古典派経済学はルイ スのみではなく、多くのバリエーションを持っている. 著者が示している上述の理論は, 移動に関する個々の 非常に細かい要因の説明法来ている. しかし, 後述 のように, 評者の「農村から都市への学働移動を左右 する基本的要因は，人口と技術進歩の大きさの差異に よる」という説等, むしろ新古典派理論が明らかにし た要因の方が，はるかに大きな影響を持つという点で ある.この点は次のコメントとも密接に関連する.

第 2 は, 多くの手段を用いた精力的な計量的分析が 行われているが, 自由度調整済み決定係数は活とんど 
が $0.2 \sim 0.4$ 程度の非常に不満足な結果となっている. また, $0.1 や 0.2$ 程度と極めて悪い結果を示している分 析も示している。 この点に関し，「クロスセクションの ミクロデータが用いられる分析として，容認されるも のである」と弁明しているが，8～9 割がモデルで説明 出来ていないゆえ，いくら弁護しても読者の容認は困 難であろう。すなわち, 自由度調整済み決定係数は次 のようになっている，表 3.4 の「省間人口移動率」の 結果は $0.4 \sim 0.5$ 強. 0.84 もあった。表 5.6 農家労働 力の就業選択は 0.429. 表 5.1 の「年間収入の規程要 因」の結果も0.3 から 0.5 弱. 表 5.4 の「農家労㗢力 年間就業日数」は $0.16 \sim 0.33$. 表 5.5 の自営行動の規 定要因 0.210. 表 5.7 の非農業雇用労働の賃金決定は $0.298 \sim 0.337$. 表 8.2 の出稼ぎ労働者全体の賃金関数 の $0.15 \sim 0.26$. 表 6.8 の労働移動率の決定要因は 0.182 $\sim 0.595$. 表 8.3 の産業別，業種別，地域別の賃金関数 の $0.115 \sim 0.689$. 表 8.4 の職業別の賃金関数の 0.184 〜 0.546. これらの低決定係数を得たということは，ま さしく新古典派がいう大きな要因が抜けていることを 示している，すなわち，1例を言うと，評者の技術進歩 のプッシュ・プル要因や人口の綱引き関係の要因が 入っている計測結果は比較的良く, 入っていない計測 結果は極めてお粗末な結果となっている.

第 3 は，本書の計量的分析も本来は同時方程式にす べき性質のものであるという点である. 例えば, 表 5.1 の非説明変数である年間収入は, 説明変数の教育や労 働参加率, 非農業就業比により影響を受けるとして推 定をしている。しかし，明らかに逆の因果が存在する。 すなわち，年間収入が上がれば教育水準が上がる。年 間収入が上がれば非農業就業比も上がる. 労働参加率 も年間収入に影響を受ける。このように, 両者は相互
依存関係を持っている。他の全ての計測モデルも，因 果は両方であり，その意味で，同時方程式にすべきも のである。特に表 6.8 はひどく，モデル自体がお互い に MR, OMR, IMR の変数を持っており, 同時方程式 の形になっているのに, 識別可能性も検討せず, 二段 階最小自乗法で推定すべき点もしていないので，推定 結果は全く「信頼出来ない物である」と言われても，反 論が出来ないであろう.

第 4 に, 「労働移動と技術進歩」の記述（P. 37）があ るが，新古典派の成果を全く理解しておらず（技術進 歩と労働力移動に関しては, レイナス＝フェイのみで はなく、筆者の研究も AJAE [1975]，CJAE [1984]， ESQ [1982］や泉田洋一編 [2005］での技術進歩のプッ シュ・プル効果等の論文があるが, 全くレビューをせ ずに新古典派の批判を行っている), 新しさがなく, 極 めて迫力のない，非常に常識的な記述に終わっている．

第 5 に, 判別関数を用いて計測しているが, その説 明がない。一般の読者には全く理解出来ないであろう. また，留学生なので，少し厳しいが，日本語の粗末さ が散見される。 今後は日本人にチェックを頼まれるこ とを希望する、スジャースタッド（Sjaastad）をスジャッ ダット, 労働力のプル理論をプール理論. また, 新古 典理論ではなく, 通常は新古典派理論が普通である, 加 速度的であるべき，非農業就業比率であるべき等，非 常に多くある，さらに，有意水準，しかも小数点以下 多くの数字が並び，きわめて見にくい表となっている. しかし，精力的，かつ前向きに一生懸命頑張っている 姿は見上げたものであり，今後とも頑張り，素晴らし い研究を益々続けて宒しいものである。

(評者：神戸大学大学院経済学研究科) 